\title{
Histological Study of Mudskipper (Periophthalmus gracilis) Gills
}

\author{
Hikmah Supriyati $^{1 *}$, Nurul Safitri Apriliani ${ }^{2}$, Muhammad Ja'far Luthfi ${ }^{1}$ \\ ${ }^{1}$ Biology Education Department, ${ }^{2}$ Biology Department, Faculty of Science and Technology, UIN Sunan Kalijaga \\ Jl. Marsda Adisucipto No. 1 Yogyakarta 55281, Indonesia. Tel. + 62-274-540971, Fax. + 62-274-519739 \\ Email: hikmahsupriyati@gmail.com
}

\begin{abstract}
Mudskipper belongs to the Gobiidae family which has respiratory adaptation to fits their habitat. Mudskipper has a different gill structure or modification of gills, this different structure allows the mudskipper to survive for a long time outside water. This study aimed to determine the histology of gills and find out whether there is a modification of gills in the mudskipper respiratory organs (Periophthalmus gracilis). Histological preparations were done using paraffin method, stained with Hematoxylin-Eosin. Data analysis was carried out in a qualitative descriptive. The results showed that there is no additional respiratory organ in the mudskipper respiration, whereas the gills have some modifications. The histological structure of mudskipper gills consists of gill arches, arteries, gill filament, primary lamellae, and secondary lamellae. The gills of mudskipper have a different structure from the general fish, which has a thick secondary lamellae with a low amount of density, the shape of the filament are short and bent. This gill structure is a form of adaptation to habitat and behavior to live outside the water in a relatively long time.
\end{abstract}

Keywords: Histology, Gills, Mudskipper

\section{INTRODUCTION}

Mudskipper lives in tropical to sub-tropical regions and spread throughout the region from the Atlantic coast. The most scattered species is the genus Periophthalmus, which is currently estimated at 18 species (Sunarni, 2013). Mudskipper is endemic biota that inhabits mangrove forests. Mudskipper can only be found in coastal areas of mangrove forests and has the ability to crawl up to land or perch on mangrove roots, has large eyes and sticking out from its head, has pectoral fins at the base of the muscles, and these fins can be bent to function like arms that can be used to crawl or jump on mud.

Mudskipper is also called as Amphibious Fish because their ability to live inside and outside the water. Aquatic medium is dominated by the presence of water pressure while in the terrestrial area is dominated by the presence of gravitational pressure. Mudskipper more often on land and return to the water to wet the gills and skin. The ability to live on land and in water makes mudskipper able to adaptation to raise the cavity contained in the gills to maintain air bubbles. This is done to provide oxygen during respiration on land (Jaafar, 2009).

Mudskipper belongs to the Gobiidae family which has respiratory adaptation to fits their habitat (Lagler et al., 1977). The ability to store oxygen reserves and survive on land long time allows mudskipper have a different gill structure than most fish in general. Other than have a different gill structure, mudskipper have an additional respiratory organ to help with breathing when on land. Modified areas are usually characterized by a large number of blood capillaries scattered in these areas to help increase air exchange during on land (Sayer, 1991).
This study aimed to determine the histological structure of mudskipper gill with respect to its adaptation to live outside water. The mudskipper respiration system is still rarely studied histologically. References on the histological structure of gills and additional respiratory organs structures of mudskipper are limited. It is necessary to do research on the mudskipper gills related to their adaptation to the environment with minimal oxygen.

\section{MATERIALS AND METHOD}

This study used five mudskippers (Periophthalmus gracilis) obtained from Samas Beach, Bantul, Yogyakarta. Furthermore, mudskipper is dissected and the head is taken to make histological preparations. Histological slides were made using the paraffin method with Hematoxylin-Eosin staining. Histological observations were carried out using microscope.

\section{RESULTS AND DISCUSSION}

\section{Histology of Mudskipper Head}

In this study, the histological slide was made by section anatomy on the mudskipper head. It aimed to know the topography and histological structure of gills. Based on observations that had carried out, it is shown that mudskipper do not have additional respiratory organ structure such as the labyrinth, pseudobranch, and diverticula. The ability of mudskipper to live outside the water is enabled using gills and assisted by the skin. This is in accordance with the research conducted by Melinda (2014) which states that mudskipper can carry out activities for a long time outside water because 
there is a layer in the epidermis of the skin, called swollen cell. The swollen cell layer serves to store water reserves to maintain the moisture of fish skin while on the land. This statement is also reinforced by Ghaffar et al (2006) which states that mudskipper breathes using gills and skin like amphibian. The topography of the gill in mudskipper head can be seen in the picture below:

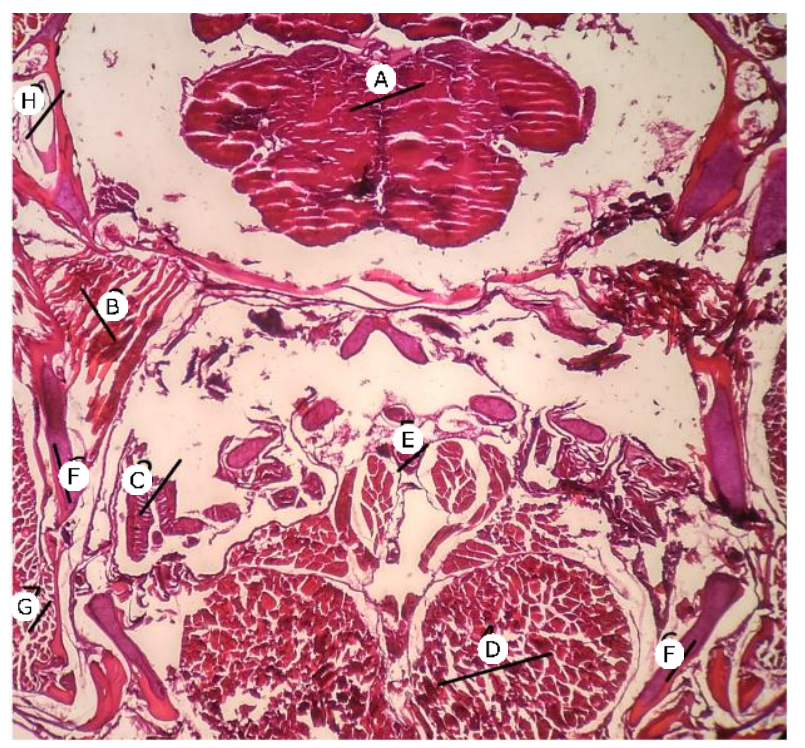

Figure 1. Histology of head part of mudskipper: (A) Telencephalon, (B) Skeletal muscle, (C) Gills, (D) Epaxial muscles, (E) Aorta, (F) Bone, (G) Striated muscle, $(\mathrm{H})$ Inner ear.

In the cross-section of the mudskipper head, we can observed the location and size of the gill. Gills of mudskipper have a relatively small size than other fish. The small size of the gills makes mudskipper have a wider opercular space to accommodate the incoming water during the respiration process. The wide opercular space around the gills allows the fish to absorb a lot of oxygen from the water that is accommodated around the gills. Nielsen (1997) said that the flow of water entering gill lamellae will be in the opposite direction to the flow of blood. The counter-current flow will increase the transfer of oxygen from water to blood. So the more water flows, the greater the oxygen transfer to the blood. Thus the presence of wider space around the gills will make the gill lamellae of mudskipper absorbed more oxygen. This is because more water volume has a higher pressure.

\section{Histology of Mudskipper Gill}

Gills are organs that serve regulate the exchange of salt and water and excretion of waste nitrogen, especially ammonia. Based on observations in this study, gills of mudskipper consist of gill arches, secondary lamellae, primary lamellae, arteries. The structure of the gill filaments is composed of thin layers of epithelium on the outside, the base membrane and pole cells as internal support (Roberts, 1989). Histology of mudskipper gills can be seen in the figure 2 .

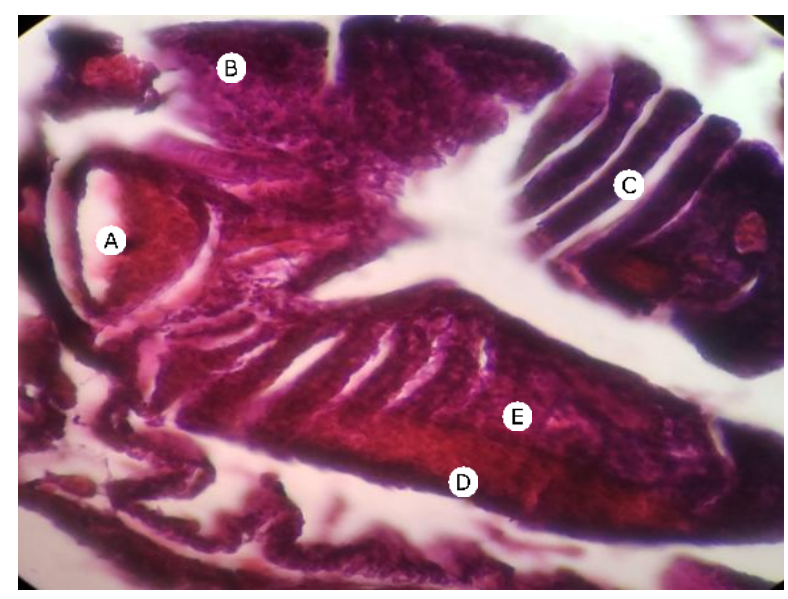

Figure 2. Histology of mudskipper gills (A) Artery, (B) Gill arch (C) Gill filaments, (D) Primary lamellae, (E) Secondary lamellae.

According to Erlangga (2007) epithelium in primary and secondary lamellae consist of several cells namely chloride cells and oval-shaped monocyte cells. Affandi and Tang (2002), stated that chloride cells serve in the exchange of salt, the removal of salt in marine fish and the extraction of salt in fresh water fish. Many chloride cells are found in the basal (proximal) part of lamellae, while mucus cells function to produce mucus (Mumford et al., 2007). On the secondary lamellae there are pillar cells that are more concentrated. The pillar cells are arranged in a row and the cells are encased by a thin, semipermeable epidermal membrane (Fauzy et al., 2014). Yonkos et al (2000) stated that the distance between pillar cells is called lacuna which connects afferent and efferent arterial blood.

Gills of mudskipper are related to their habitat adaptation. When the counter-current respiration process takes place on the gills, blood on the lamellae will take $80-90 \%$ oxygen from the water that passes through the lamellae. According to (Hazelhoft and Evenhuis, 1952 in Nielsen, 1997), lamellae along its entire length serves as a place for taking oxygen from water. Water leaving gills will lose $80-90 \%$ of the initial oxygen content. Thus the water leaves the lamellae with the remaining oxygen content of 10-20\%. Thick lamellae of mudskipper allow more capillaries, to maximize the ability in absorbing oxygen from water, probably much more than $80 \%$, while wider distances between capillaries allow for more water flow. Both of these are likely to make mudskipper more capable of adapting to oxygen-deprived water.

The thick structure of lamellae enable to absorb oxygen from the water efficiently. Thick lamellae is allowed related to the adaptation of mudskipper when life is landed for a long time. This structure prevents the lamellae from sticking together and is not easy to fuse when bending as exposed to outside air. The thick lamellae structure makes the mudskipper able to store 
and absorb oxygen when the operculum closes. Hughes and Datta Munshi (1979) reported that thick lamellae an air-breathers act as an oxygen-conserving device or to prevent oxygen loss when the surrounding water has a low oxygen tension. Based on histological observations, the structure of mudskipper gill has a non-straight shape and bent on its filaments. The existence of a bent shape is likely to benefit the gill of mudskipper to expand the area of oxygen absorption.

This research is in accordance with Wilson et al (1999) in Melinda, (2016), that is, the normal condition of lamellae in amphibian fish is thicker and bent. This is reinforced by the study of Ghaffar et al (2006) entitled "Fine Structure of Gills and Skins of Amphibious Mudskipper, Periophthalmus chrysospilos (Bleeker, 1852) and a Non-Amphibious Goby, Favonigorus Reichel (Bleeker, 1853)" This study shows that amphibian fish (Periophthalmus chrysospilos) have short, thick and bent gill filaments. Whereas non-Amphibious fish have straight, long and thin filaments. In addition, non-amphibious fish also have more dense lamellae than amphibians.

\section{CONCLUSIONS}

Based on the histological, it can be concluded that mudskipper does not have additional respiratory organ structure but the gill of mudskipper has a different structure than other fish. Gills of mudskipper have a relatively small size. The small size of the gills makes mudskipper have a wider opercular space to accommodate the incoming water during the respiration process. Histologically, the gills of mudskipper consist of gill arches, arteries, gill filaments, primary lamellae, and secondary lamellae. The gills of mudskipper have a secondary lamellae structure that is thick with a low density, the filament are short and bent. Thick lamellae of mudskipper allows more capillaries to be more efficient in absorbing oxygen from water, while wider distances between capillaries allow for more water flow. Both of these are likely to make mudskipper more capable of adapting to oxygen-deprived water.

\section{REFERENCES}

Affandi, R., dan Tang, U. 2002. Fisiologi Hewan Air. Riau: University Riau Press

Anggie, R. S. 2008. Studi histopatologi insang, usus dan otot ikan Gurami(Osphronemus gournmy) akibat infestasi parasit protozoa di desa Carang Pulang Dramaga Bogor. Skripsi. Fakultas Kedokteran Hewan, Institut Pertanian Bogor, Bogor.

Erlangga. 2007. Efek pencemaran perairan sungai kampar di provinsi Riau terhadap ikan Baung (hemibagrus nemurus). Tesis. Sekolah Pascasarjana Institut Pertanian Bogor, Bogor.

Fauzy, A., Tarsim, dan A. Setyawan. 2014. Histopatologi organ Kakap Putih (Lates calcarifer) dengan infeksi Vibrio alginolyticus dan Jintan Hitam (Nigella sativa) sebagai imunostimulan. e-Jurnal Rekayasa dan Teknologi Budidaya perairan, 3(1):319-325.

Fujaya .2008. Fisiologi Ikan . Jakarta: PT Rineka Cipta

Hazelhoff, E. H and Evenhuis, H.H. 1952. Importance of the "counter-current principle" for the oxygen uptake in fish. Nature, Lond 160-177.

Hughes G.M., Datta Munshi J.S. 1979. Fine structure of the gills of some Indian air-breathing fishes. Journal of Morphology 160: 169-193.

Jaafar Z, Perrig M, and Chau L.M. (2009). "Periophthalmus variabilis (Teleostei: Gobiidae: Oxudercinae), a valid species of mudskipper, and a re-diagnosis of Periophthalmus novemradiatus". Zoological Science 26: 309-31

Laurent, Posschelle \& Dunel-Erb, Suzanne. (1984). 9 The Pseudobranch: Morphology and Function. Gills, Part B: Ion and Water Transfer. 10. 285-323. 10.1016/S1546-5098(08)60188-0.

Mazlan A.G., Masitah A., Mahani M.-C. 2006. Fine structure of gills and skins of the amphibious mudskipper, Periophthalmus chrysospilos Bleeker, 1852, and a non-amphibious goby, Favonigobius reichei (Bleeker, 1853). Acta Ichthyol. Piscat. 36 (2): 127-133.

Melinda, Y.M. 2014. Struktur Kulit Ikan Gelodok (Periophthalmul gracilis Egget, 1935) di Pasir Mendit dan Sungai Bogowonto Kulonprogo. Fakultas Biologi UGM. Yogyakarta

Mumford, S., Jerry H., Charlie S., John M., Beth M. dan Vicki B. 2007. Fish Histology and Histopathology. USFWS-NCTC

Murdy E.O. (1989). Taxonomic Revision and Clodistic Analysis of the Oxudercine Gobies ( Gobidae Oxudercinae). Records of the Australian museum supppl; 11: 1 - 93.

Nielsen, Knut Schmidt. 1997. Animal Physiology: Adaption and Environment. United State of America: Cambridge University Press.

Puspowardoyo \& Djarijah, A. 2002. Pembenihan dan Pembesaran Lele Dumbo Hemat Air. Yogyakarta: Penerbit Kanisius

Roberts, J. S. 1989. Fish Phatology. Second Edition. Bailliere Tindall, London.

Sayer, M.D.J and J. Davenport. 1991. Amphibious fish: why do they leave water? Review in Fish Biology and Fisheries. 1: 159-181.

Yang, Sheng-Hui et all. 2014. The lamellae-free-type pseudobranch of the euryhaline milkfish (Chanos chanos) is a $\mathrm{Na}+\mathrm{K}+$ ATPase-abundant organ involved in hypoosmoregulation. Journal homepage: Comparative Biochemistry and Physiology, part A 170 (2014) 15-25

Yonkos, L. T., Daniel J. F., Renate R. dan Andrew S. K. 2000. Atlas of Fathead Minnow Normal Histology. An online publication of the University of Florida. Aquatic Pathobiology Laboratory ( http://aquaticpath.epi.ufl.edu/fhm). 
THIIS PAGE INTENTIONALLY LEFT BLANK 